\title{
A two-way shuttlebox for testing nonhuman primates
}

\author{
DOUGLAS K. RUSH \\ University of Wisconsin, Madison, Wisconsin 53706
}

\begin{abstract}
The construction of a two-way shuttlebox suitable for testing nonhuman primates, such as rhesus macaques, is described. Special mention is made of those aspects of design and construction necessary to prevent subjects from solving experimental tasks in unforeseen and unwanted ways.
\end{abstract}

Since the first description of its construction (Mowrer \& Miller, 1942), the two-way shuttlebox apparatus has been extensively used in the study of both aversive (Solomon \& Wynne, 1953) and appetitive (Hollis \& Overmier, 1973) conditioning in a wide variety of species: for example, rats (McAllister, McAllister, \& Douglass, 1971), dogs (Solomon, Kamin, \& Wynne, 1953), sheep (Van Gelder, 1975), fish (Bintz, 1971), cats (Thomas \& DeWald, 1977), mice (Anisman, deCatanzaro, \& Remington, 1978), monkeys (Pribram \& Weiskrantz, 1957), pigs (Dantzer \& Mormede, 1976), and humans (Turner \& Solomon, 1962). For rats, mice, dogs, cats, pigs, and sheep, the basic design outlined in the first paper (Mowrer \& Miller, 1942) has proved useful, excepting, of course, changes in overall dimension to accommodate size differences between these animals. For certain other species, however, more radical design modifications have been required in order to accommodate the environmental requirements or motor capabilities of the organism being tested.

This report details the construction of a two-way shuttlebox for medium-sized primates $(3-15 \mathrm{~kg})$ such as rhesus monkeys. Although nonhuman primates (in all cases, rhesus macaques) have been previously employed as subjects in shuttlebox apparatus (Pribram \& Weiskrantz, 1957; Stewart \& Ades, 1951; Weiskrantz, 1956), no mention was made of specific methodological problems or design modifications.

The construction of the shuttlebox reported here was guided primarily by knowledge of the motor capabilities of rhesus monkeys and their well-known use of curiosity and exploration to foil an experimenter's best intentions. Modifications in our original design were necessary because of the unusual approaches and responses used by the subjects to solve experimental problems.

This research was supported in part by U.S.P.H.S. Grant MH-28485 from the National Institute of Mental Health, by Grant BNS77-06802 from the National Science Foundation, and by funds from the University of Wisconsin Graduate School. Requests for reprints should be sent to D.K. Rush, Psychologisches Institut II, Universität Düsseldorf, Universitäts-str. 1, 4000 Düsseldorf, West Germany.

\section{CONSTRUCTION}

The system consists of two stainless steel monkey housing cages, each of which is open on the top, bottom, and one side. To form the shuttlebox, the open sides of the cages are joined together, resulting in a rectangular box-like apparatus measuring $152.4 \mathrm{~cm}$ long, $76.2 \mathrm{~cm}$ high, and $76.2 \mathrm{~cm}$ wide (Figure 1). The top of each half of the shuttlebox is covered with .64-cm-thick clear Plexiglas to permit viewing of subjects via closed circuit television (CCTV). The Plexiglas is fastened to the shell of the shuttlebox with wing nuts to permit easy removal for cleaning. Door openings $22.9 \mathrm{~cm}$ high and $27.9 \mathrm{~cm}$ wide are cut into each end of the shuttlebox. Vertical movement of the stainless steel doors (not depicted in Figure 1) occurs in channels welded on each side of each door opening.

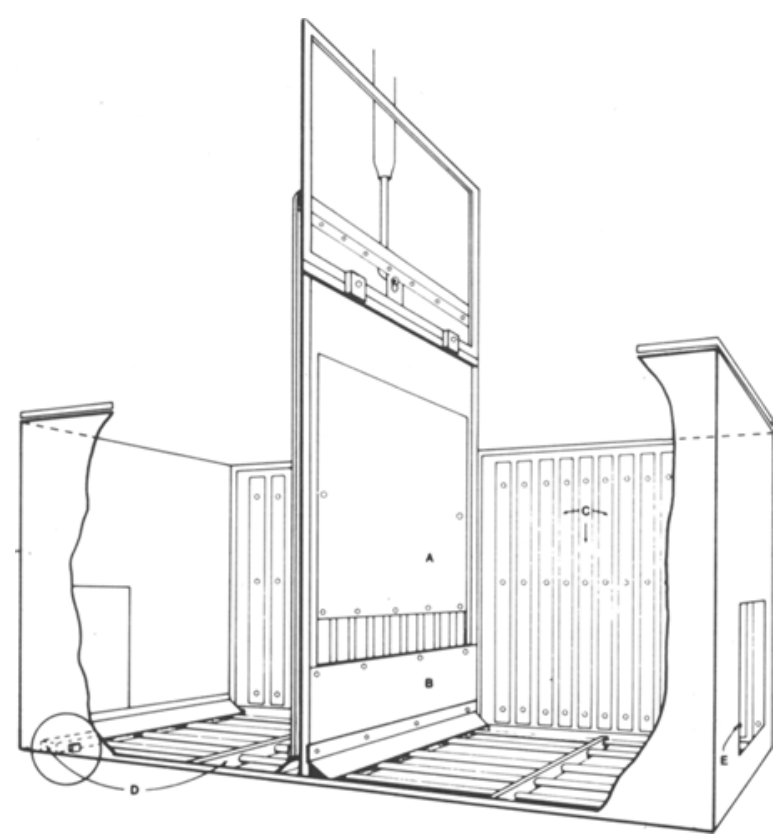

Figure 1. Cutaway drawing of shuttlebox. Position of one of the microswitches is circled. $A=$ guillotine door, $B=$ barrier, $\mathrm{C}=$ wall strips, $\mathrm{D}=$ Plexiglas strips supporting grid floor, $\mathrm{E}=$ door for entry and removal of subjects. 
Two independently mounted grid floors, one in each side of the shuttlebox, are constructed from 21 stainless steel rods, $.64 \mathrm{~cm}$ in diameter, spaced $3.18 \mathrm{~cm}$ center to center. The rods are supported at each end by $1.27 \mathrm{~cm}$ thick $\times 3.8 \mathrm{~cm}$ high Plexiglas strips and in the middle by a $.64 \mathrm{~cm}$ thick $\times 3.8 \mathrm{~cm}$ high Plexiglas strip. The Plexiglas strips on the outside end of each floor are drilled and tapped to accommodate the threaded grid bars. Each threaded bar is fastened to the inside strip with two nuts, one on either side of the Plexiglas. The outside nut holds a spade lug in place which is used to attach the wires from the shock scrambler for the delivery of shock.

Each of the two grid floors is fitted with $1.59 \times 5.72$ $\mathrm{x} 2.54 \mathrm{~cm}$ (height $\mathrm{x}$ length $\mathrm{x}$ width) Plexiglas blocks that are glued and bolted to each comer of the Plexiglas strips on the ends of the grid bars. (Refer to the lower left-hand corner of Figure 1 and, for more detail, to Figure 2.) Each floor is mounted to the shuttlebox by passing a $5.08 \mathrm{~cm}$ bolt $.95 \mathrm{~cm}$ in diameter up through a hole in a corner bracket welded in each corner of the shuttlebox frame, placing a .64-diam spring (4 turns per $2.54 \mathrm{~cm}$ ) over the bolt, and securing the bolt to the Plexiglas with a nut on each side (Figure 2). Washers are placed under the metal corner bracket and on either end of the spring.

This arrangement allows the spring-mounted floor to move vertically through a distance of approximately $1.27 \mathrm{~cm}$ and is used to record the location of the sub. ject. A microswitch (Model BZ-2RW80-A2) is attached to the supporting frame of the shuttlebox (not depicted in Figure 1) under the four comers of each floor. Movement of the floor, and, consequently, of the bolt heads due to the weight of a subject, results in closure of the switches. This allows for measures of the subject's location.

To prevent subjects from perching on the Plexiglas strips at each end of the grid floor, sheet stainless steel is bent at a $45-\mathrm{deg}$ angle and attached to the inside of the shuttlebox (Figure 1) to cover the Plexiglas. These

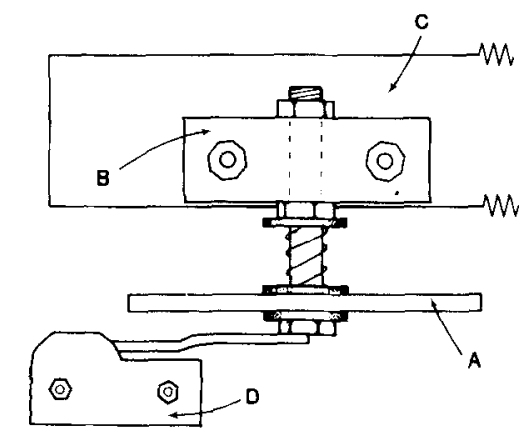

Figure 2. Detailed drawing of switch mechanism used to record position of subject in shuttlebox. $A=$ piece of stainless steel welded in corner of shuttlebox frame, $B=$ Plexiglas block, $\mathrm{C}=$ Plexiglas strip on end of grid floor, $\mathrm{D}=$ microswitch. 45-deg pieces in the center of the shuttlebox are attached to a fixed barrier $30 \mathrm{~cm}$ high formed from two sheets of stainless steel separated by Plexiglas and connected with nylon bolts. This arrangement allows the delivery of two different polarities of shock to the two sides of the barrier and prevents subjects from perching.

Following preliminary testing of subjects, a guillotine door was added to prevent a high rate of intertrial responding that was found to characterize our rhesus monkeys. This door is constructed by attaching a sheet of stainless steel to each side of a larger piece of Plexiglas with nylon bolts. The large piece of Plexiglas is raised and lowered by a hydraulic ram using positive air pressure of $2.8 \mathrm{~kg} / \mathrm{cm}^{2}$. When raised, it allows subjects to cross from one side of the shuttlebox to the other through a $23 \mathrm{~cm}$-high opening. The guillotine door is attached to the plunger of the ram, and the plunger case is attached to a superstructure mounted above the shuttlebox (partially depicted in Figure 1). Solenoid valves control the opening and closing of the door.

Interior lighting is provided by fluorescent lights positioned above each side of the shuttlebox. Incandescent lights are mounted on each side; these can be used as conditional stimuli (CSs). A tone generator (Sonalert) placed on the center line of the shuttlebox can also be used as a CS. A horizontally mounted television camera (Panasonic, Model WV-200P), $1.2 \mathrm{~m}$ above the top of the shuttlebox, and a mirror placed at a 45 -deg angle $15.2 \mathrm{~cm}$ in front of the $8.5-\mathrm{mm}$ lens allow viewing of subjects via CCTV.

As originally constructed, each of the side walls of the shuttlebox was fitted with $71.1 \mathrm{~cm}$ stainless steel sheets insulated from the shell of the box by Plexiglas and nylon bolts. During the course of an experiment in which subjects were required to learn an active/passive avoidance discrimination, 4 of 14 subjects learned to perform a response that avoided shock in a nonexperimentally defined fashion (Rush, Mineka, \& Suomi, in press). Subjects bounced back and forth between the side walls in such a way that the two side walls were not touched simultaneously.

To prevent this behavior, the stainless steel wall sheets were replaced with $172.54-\mathrm{cm}$-wide stainless steel strips mounted vertically $1.27 \mathrm{~cm}$ apart on $71.1 \mathrm{~cm}^{2}$ sheets of Plexiglas. These strips permit the administration of scrambled shock to subjects in a manner similar to the grid floors. A subject attempting to bounce back and forth between the walls receives shock from the adjacent strips of each wall.

\section{EXPERIMENTAL USE OF THE APPARATUS}

Four male and three female rhesus monkeys (Macaca mulatta) 34 years old were tested for active avoidance acquisition. Forty conditioning trials were administered using a $45-\mathrm{sec}$ variable-interval (VI) reinforcement schedule. The opening of the guillotine door and the 


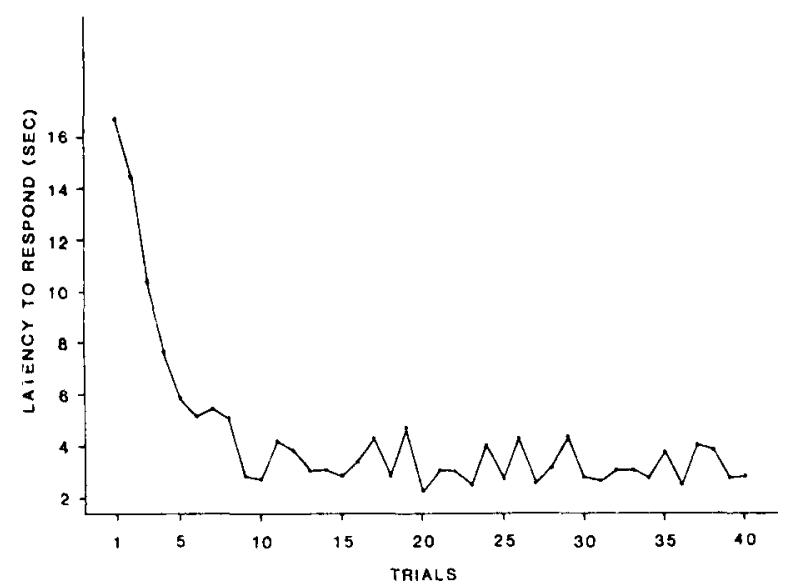

Figure 3. Mean response latency in each of the 40 trials of active avoidance acquisition.

onset of a $3-\mathrm{kHz}$ tone, which raised the noise level $10 \mathrm{~dB}$ over that provided by a white noise generator, served as a compound discriminative stimulus. If the subject did not respond within $10 \mathrm{sec}$ of the beginning of the trial, $3.5-\mathrm{mA}$ scrambled shock was delivered to the grid floor and walls of one side of the shuttlebox. Escape over the barrier to the other side resulted in termination of the trial, that is, termination of the tone and closing of the guillotine door. If the animal failed to go over the barrier after shock onset, the trial terminated automatically in $30 \mathrm{sec}$.

Figure 3 shows that subjects rapidly acquired the avoidance response. By Trial 4 the mean response latency for the group was less than $10 \mathrm{sec}$; by Trial 9 the mean response latency was approximately $3 \mathrm{sec}$, a response speed which was maintained throughout the session.

The apparatus described here has been used for Sidman avoidance and the go/no-go discrimination problem. In testing over 50 monkeys, equipment failure or damage has been rare.

\section{REFERENCES}

Anigman, H., deCatanzaro, D., \& Remington, G. Escape performance following exposure to inescapable shock: Deficits in motor response maintenance. Journal of Experimental Psychology: Animal Behavior Processes, 1978, 4, 197-218.

Bintz, J. Between- and within-subject effect of shock intensity on avoidance in goldfish (Carassius auratus). Journal of Comparative and Physiological Psychology, 1971, 75, 92-97.

Dantzer, R., \& Mormede, P. Fear-dependent variations in continuous avoidance behavior of pigs: I. Lack of effect of diazepam on performance of discriminative fear conditioning. Psychopharmacology, 1976, 49, 69-73.

Hollis, K. L., \& Overmier, J. B. Effect of inescapable shock on efficacy of punishment of appetitive instrumental responding by dogs. Psychological Reports, 1973, 33, 903-906.

McAllister, W. R., McAllister, D. E., \& Douglass, W. K. The inverse relationship between shock intensity and shuttlebox avoidance learning in rats: A reinforcement explanation. Journal of Comparative and Physiological Psychology, 1971, 74, 426-433.

Mowrer, O. H., \& Miller, N. E. A multiple purpose learningdemonstration apparatus. Journal of Experimental Psychology, 1942, 31, 163-170.

Pribram, K. H., \& Weiskrantz, L. A comparison of the effects of medial and lateral cerebral resections on conditioned avoidance behavior of monkeys. Journal of Comparative and Physiological Psychology, 1957, 50, 74-80.

Rush, D. K., Mineka, S., \& Suomi, S. J. The effects of control and lack of control on active and passive avoidance in rhesus monkeys, Behavior Research and Therapy, in press.

Solomon, R. L., KAmin, L. J., \& Wynne, L. C. Traumatic avoidance learning: The outcomes of several extinction procedures with dogs. Journal of Abnormal and Social Psychology, 1953, 48, 291-302.

Solomon, R. L., \& Wynne, L. C. Traumatic avoidance learning: Acquisition in normal dogs. Psychological Monographs: General and Applied, 1953, 67(4, Whole No. 354).

Stewart, J. W., \& Ades, H. W. The time factor in reintegration of learned habit lost after temporal lobe lesions in the monkey (Macaca mulatta). Journal of Comparative and Physiological Psychology, 1951, 44, 479-486.

Thomas, E., \& DEW ALD, L. Experimental neurosis: Neuropsychological analysis. In J. D. Maser \& M. E. P. Seligman (Eds.), Psychopathology: Experimental models. San Francisco: Freeman, 1977.

Turner, L. H., \& Solomon, R. L. Human traumatic avoidance learning: Theory and experiments on the operant-respondent distinction and failures to learn. Psychological Monographs: General and Applied, 1962, 76(40, Whole No. 559).

Van Gelder, G. A. Behavioral toxicologic studies of Dieldrin, DDT, and Ruelene in sheep. In B. Weiss \& V. G. Laties (Eds.), Behavioral toxicology. New York: Plenum, 1975.

Weiskrantz, L. Behavioral changes associated with ablation of the amygdaloid complex in monkeys. Journal of Comparative and Physiological Psychology, 1956, 49, 381-391.

(Received for publication December 4, 1981; revision accepted December 31, 1981.) 